\title{
FORGÓGÉPEK ÜZEM KÖZBENI MOZGÁSÁNAK PRÓBAPADI ÉS IPARI VIZSGÁLATA
}

\author{
Dr. PhD Szabó József Zoltán \\ Adjunktus, Óbudai Egyetem, Bánki Donát Gépész és Biztonságtechnikai Mérnöki Kar, Budapest
}

\section{SUMMARY}

The significance of predictive maintenance and vibration diagnostic increasing continuously in every area of industry. Vibration diagnostics delivers considerable economic benefits for machinery operation. Vibration measurement can show up mechanical problems and harmful effects which acts on the parts throughout the operating period of the machine. This paper describes an alternative method of vibration diagnostic with „Vibshape"moving-animation software. With this program and an vibration analyser the moving of the machines, and the mechanical structures can be visible.

This article shows the basic knowledge of vibration diagnostic with animation program, and a case study from my practice. The case study shows the moving of the machines in main mechanical problems, for example resonance and electrical problem. Across of the case study we can see the resonance problem of a supporting structure and a big blower rotor bar crack.

Kulcsszavak: forgógép, mozgás-animáció, rezgésdiagnosztika, rezonancia, kalicka-törés.

\section{BEVEZETÉS}

A korszerú karbantartási rendszereket egyre szélesebb körben alkalmazzák a gépek våratlan tönkremenetele, a termeléskiesés csökkentése érdekében. Az állapotfüggő karbantartási stratégia legfontosabb bázisa a gépek rezgésdiagnosztikai vizsgálata, amely lehetőséget teremt arra, hogy a károsító hatásokat üzem közben, teljes terhelés alatt fedezzük fel. A rezgésdiagnosztika gazdásági előnye elsősorban abban nyilvánul meg, hogy a meghibásodások elöre jelzésével elkerülhetők egy termelési folyamat, vagy akár egy egész gyár üzemképességét veszélyeztető müszaki katasztrófa helyzetek.

A cikk célja egy speciális rezgésdiagnosztikai módszer, a mozgás-animáció elméleti összefoglalása, valamint esettanulmányokon keresztül az oktatásban és az iparban való hatékony alkalmazhatóságának bemutatása. Ezzel a módszerrel a gépszerkezetek üzem közben végzett mozgásai láthatóvá tehetök, elemezhetök, segítségével feltárható a gép hibás müködésének eredete. A mozgás-animációs vizsgálatban szerzett elméleti és gyakorlati tapasztalataimat egy próbapadi kísérleten, illetve egy nagy teljesítményủ légfúvó hajtómotor kalicka repedéses meghibásodásának esettanulmányán keresztül mutatom be.

\section{FORGÓGÉPEK ÖSSZETETT REZGÉSEI}

Definíció szerint a rezgés valamely fizikai mennyiség változásának egy referencia hely körüli, ismétlődően növekvő és csökkenö folyamata az idö függvényében. A géprezgések legfontosabb jellemzői az idő függvényében a $g(t)=A \sin (\omega t+\varphi)$ törvényszerüséggel változnak, ahol az A - amplitúdó az $\omega$ - körfrekvencia (1/s) (periódusidő) és a $\varphi$ - kezdő fázisszög állandók. A műszaki diagnosztikai méréseknél a legnagyobb jelentőséggel a periodikus, harmonikus rezgések bírnak, amelyek elméletben előállíthatók egy meghatározott hosszúságú $\omega$ szögsebességgel forgó vektor vetületeként. [1]

A valóságos forgógépek sokféle alkatrészből. épülnek fel, különböző alkatrészeik különféle rezgéseket hoznak létre, amint azt az l.a.ábra is szemlélteti. A sokféle frekvenciájú, különféle amplitúdójú harmonikus rezgésösszetevők adják a géptesten érzékelhető komplex periodikus időjelet. A gyakorlatban már a rezgések érzékelése után Fourier-transzformációt alkalmaznak az időfüggvények frekvencia függvényekké történö áttranszformálásához, melynek folyamata az 1.b. ábrán kísérhetö figyelemmel. A rezgésspektrum tehát a rezgési 
folyamat különböző frekvenciájú összetevőinek Fourier-transzformált (FFT) összessége. A spektrumban a derékszögủ koordinátarendszer abszcisszájára a frekvenciát Hz-ben (esetleg a percenkénti ciklusszámot CPM-ben), ordinátájára pedig az összetevők amplitúdójának Peak (csúcs), Peak-to-Peak (PTP), vagy effektív (RMS) értékét mérik fel.

\section{1. ábra: a.) A forgógépek összetett rezgései transzformáció edménye}

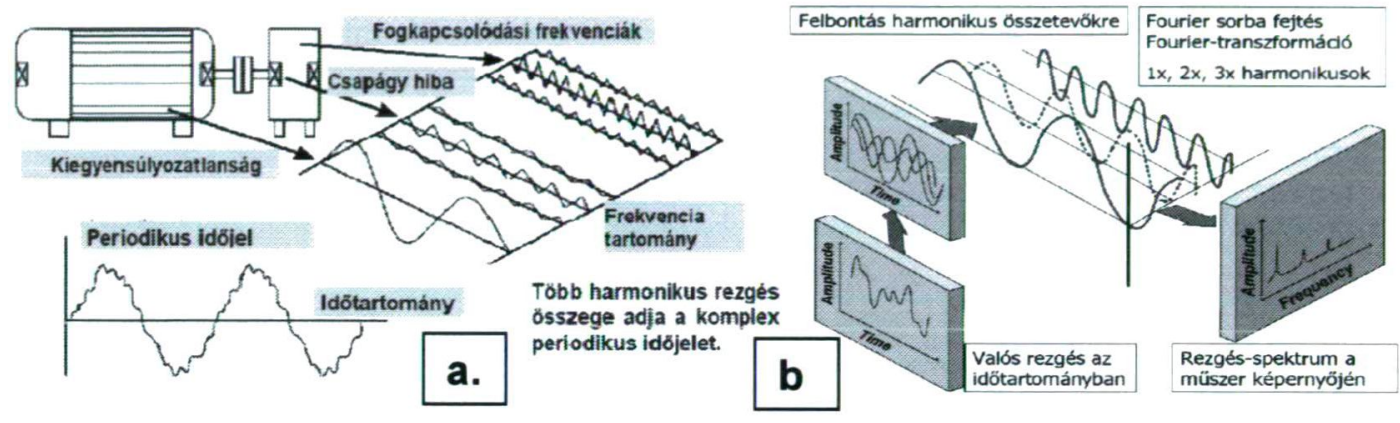

\section{b.) A Fourier}

\section{Forrás: saját szerkesztésủ ábrák}

\subsection{A MOZGÁS-ANIMÁCIÓS VIZSGÁLATI ALAPJAI}

A testek mozgásának leírására a mozgásfüggvényeket alkalmazunk. Az x,y,z Descartes koordináta rendszerben elhelyezkedő test tetszőleges $\mathrm{P}\left(\mathrm{x}_{\mathrm{P}}, \mathrm{y}_{\mathrm{P}}, \mathrm{Z}_{\mathrm{P}}\right)$ pontjának helyzetét egy $\mathbf{r}$ helyvektor segítségével határozhatjuk meg. A 2.a. ábrán látható $\mathrm{P}(\mathrm{x}, \mathrm{y}, \mathrm{z})$ pont (amely lehet egy gépen lévő pont is) elmozdulásakor $\mathrm{x}, \mathrm{y}$ vagy $\mathrm{z}$ koordináta értéke változik meg, a pont helye a mért kitérés $(\boldsymbol{\Delta s})$ értékével mozdul el a $\mathrm{P}^{\prime}\left(\mathrm{x}_{1}, \mathrm{y}_{1}, \mathrm{z}_{1}\right)$ helyzetbe. A periodikus rezgőmozgást végző pont mozgásának meghatározásánál a problémát az jelenti, hogy a gép egy pontja gyakorlatilag a tér minden irányában végez szinuszos mozgást, amelynek frekvenciája azonos, de a tér különböző irányaiban más amplitúdóval rendelkezik, amint azt a 2.b. ábra is mutatja. A térben mozgó $P$ pont pillanatnyi helyzete a rezgés-amplitúdóval és az erre a pillanatra vonatozó referencia ponttól mért fázisszöggel írható le. [1], [2]

2. ábra: a. A „P” pont térbeli helyzete b. Szinuszos rezgőmozgása c. A kitérés és fázisszög kapcsolata

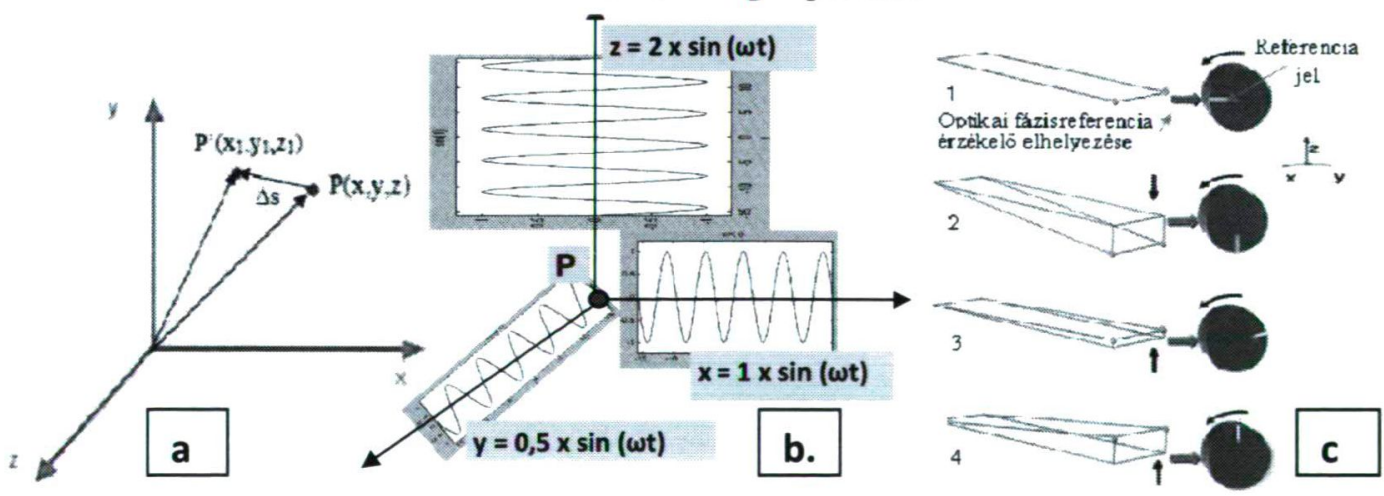

Forrás: saját szerkesztésủ ábrák 
A korszerủ mérőmüszerek egyszerre képesek a gép kiválasztott pontjaihoz tartozó fázisszög és a rezgés kitérés megváltozását mérni egy un. referencia (trigger) jelhez viszonyitva. Ezt figyelhetjük meg a 2.c. ábrán látható egy irányú (függőleges) rezgőmozgást végző lemez esetében, melynél az indítási pozícióban a kitérés és a fázisszög egyaránt 0 értéket vesznek fel. A forgórész elfordulásával szinkronban a fázisszög $90^{\circ}$-os és $270^{\circ}$-os megváltozásához, a lemez lefelé, vagy felfelé történő negatív, vagy pozitív kitérése tartozik.

\section{KÍSÉRLETEK KIEGYENSÚLYOZATLANSÁG PRÓBAPADI VIZSGÁLATÁRA 3.1. A PRÓBAPADI VIZSGÁLAT ELŐKÉSZÍTÉSE, A MÉRÉSEK VÉGREHAJTÁSA}

A gépek üzem közbeni valóságos elmozdulásai a legtöbb esetben olyan kicsik, vagy olyan gyorsak, hogy az emberi érzékszervek nem képesek feldolgozni öket. Megjelenítésük a szakemberek régi vágya, hiszen a látható elmozdulások olyan többlet információt hordoznak a gép üzem közbeni valóságos viselkedéséről, melyet más diagnosztikai módszerekkel, vagy például időigényes és komoly számítástechnikai apparátust igénylő „véges-elemes” szoftverekkel csak megközelíteni tudunk.

\section{3. ábra: A kísérlet alapjául szolgáló mérési összeállítás a "VIBROTESTER" próbapadon}

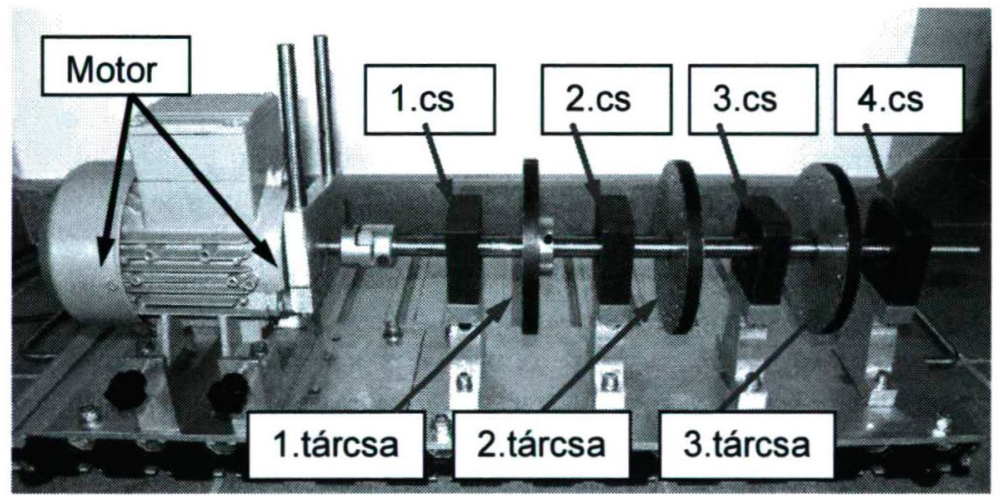

Forrás: saját fotó

A mozgás-animációs módszer használatát elöször egy modellkísérleten szemléltetem a „VIBROTESTER” nevű rezgésdiagnosztikai próbapadon. A kísérletekhez a 3. ábrán látható négy helyen csapágyazott három tárcsából álló kísérleti forgórészt terveztem, amelyen az egyes tárcsákon egymás után létrehozott kiegyensúlyozatlanság hatását vizsgálom a mozgásanimációs módszerrel.

A mozgás-animációs vizsgálati folyamat a modell tervezésével kezdődik, melyet a 4 . ábrán a Vibshape ${ }^{\mathrm{TM}}$ szoftver mérés tervező képernyőjén kísérhetjük figyelemmel. A szoftverben pontos geometriai arányok betartásval, téglatest és hengeres elemekböl, valamint ezeket összekötő vonalakból építhetjük fel valóságos berendezésünk egyszerüsített vázát egy Descartes-koordináta rendszerben. A modell megalkotása után a mérési pontokat és a valóságban is hozzáférhető, mérhető mérési irányokat kell rögzíteni. Ennek jelentősége azért nagy, mert az méréseket ennek a szigorú mérési sorrendnek megfelelően kell végrehajtani.

A gép fordulatszámának ismeretében tervezni kell azokat az un. „mérési sorozatokat” is, amelyek segítségével a különféle üzemállapotokat és mérési fordulatszámokat el tudjuk különíteni egymástól. A szoftver mérési eredmény táblázatot rendel a sorozathoz a mérési pontokkal, irányokkal, valamint az ezekhez tartozó amplitúdó és fázisszög értékekkel. 


\section{4. ábra: A vizsgálat tárgyát képező modell a „Vibshape” szoftver tervezési képernyőjén}

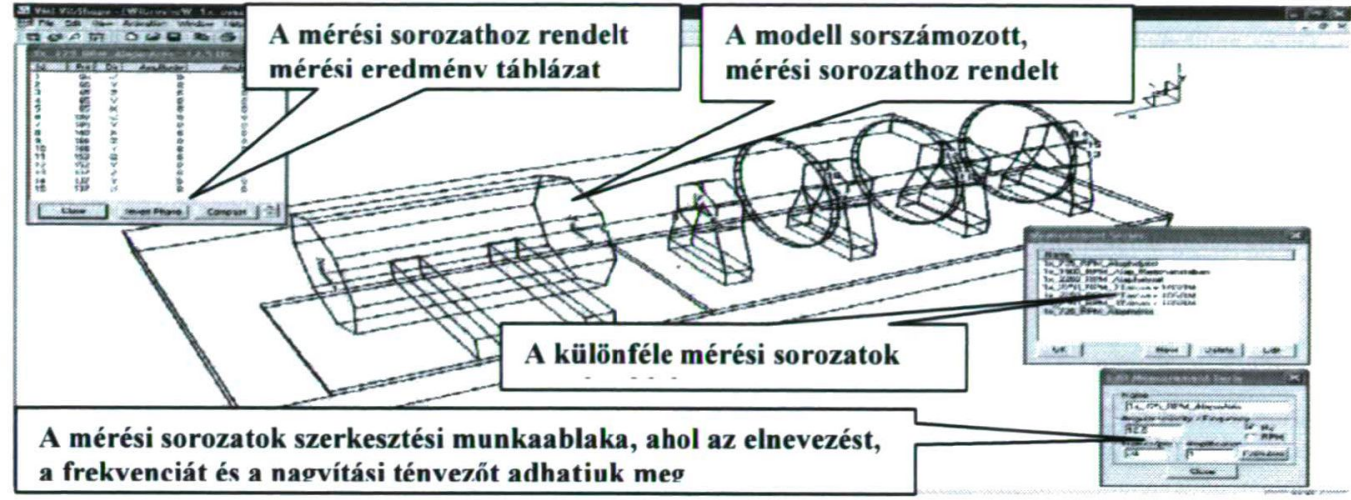

Forrás: saját szerkesztésủ ábra

A vizsgálat során egy mindössze 10 gr tömegü csavarral egymás után „elrontva” az 1, 2, és 3 tárcsákat olyan mértékủ kiegyensúlyozatlanságot okozok, amely a mozgó animációban egyértelmủen beazonosítható és követhető elmozdulást, üzemállapot változást okoz. Az amplitúdó és fázisadatok rögzítését a modell megtervezett mérési helyinek és irányainak ismeretében egy erre alkalmas Easy Viber 64 rezgésanalizátorral végeztem el. A mérés ennél részletesebb ismertetésétől a cikk terjedelme és fekete-fehér jellege miatt kell eltekintenem.

\subsection{A PRÓBAPADON VÉGZETT MOZGÁS-ANIMÁCIÓS KÍSÉRLET EREDMÉNYEI}

A próbapadi vizsgálatokkal a módszer gyakorlati alkalmazhatóságát kívánom bizonyítani, forgó gépek müszaki állapotváltozási folyamatának követése szempontjából. Arra keresem a választ, hogy kimutatható-e a fordulatszám, a rezonanciában való üzemelés műszaki állapotra gyakorolt hatása, illetve milyen változást okoz a tárcsák tömegváltozásának helye és mértéke?

Mérési eredményként egy olyan 3 dimenziós mozgó képet kapunk, melyet akár animáció közben is minden irányban körbeforgathatunk, kinagyíthatunk, tehát a gép egészét és a kisebb részek mozgását is elemezhetjük, értékelhetjük. A mozgást, lásd 5.ábra, a szélső helyzetekben akár meg is állíthatjuk, így a kimerevített képen az eltérések még jobban láthatóvá válnak.

\section{5. ábra: Az 5. animációs mérési sorozat eredménye +10gr tömeg, $22501 / \mathrm{min}=37,5 \mathrm{~Hz}$ fordulatszámon}

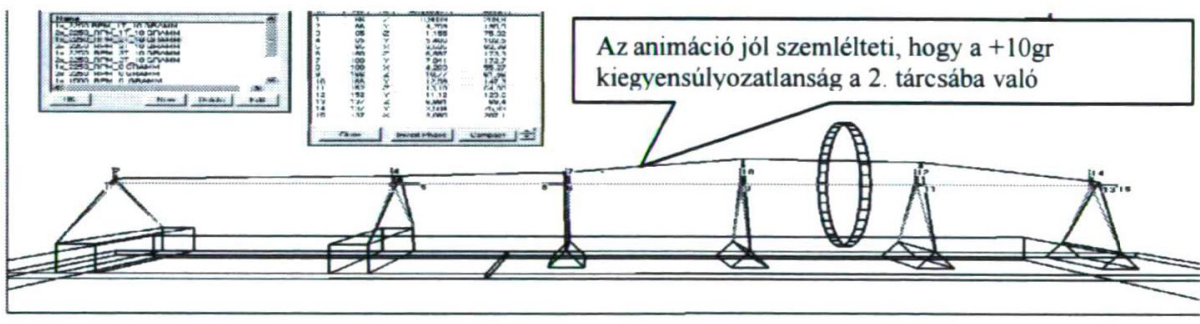

Forrás: saját szerkesztésủ ábra

E cikk lapjain nehéz egy három dimenzióban mozgó objektum ábrázolása, ezért az elvégzett hat mérési sorozatból mindössze egy egyszerüsített kimerevített kép bemutatására van lehetőségem a kísérletek eredményeinek szemléltetésére. Az 5.ábra 2. számú tárcsa 10 gr tömeg okozta kiegyensúlyozatlanságát mutató kép azonban úgy érzem önmagáért beszél. 


\section{A MOZGÁS-ANIMÁCIÓ ALKALMAZÁSA AZ IPARI GYAKORLATBAN}

A mozgás-animációt nem csak kísérleti célokkal, hanem az iparban ,éles helyzetekben” is számos esetben alkalmaztam már diagnosztikai gyakorlatom során. Esettanulmányomban egy olyan műszaki problémára mutatok példát, amelyben rezgésdiagnosztikai, mozgás-animációs sőt endoszkópos szaktudásra is szükség volt a gép üzemképességének visszaállításához.

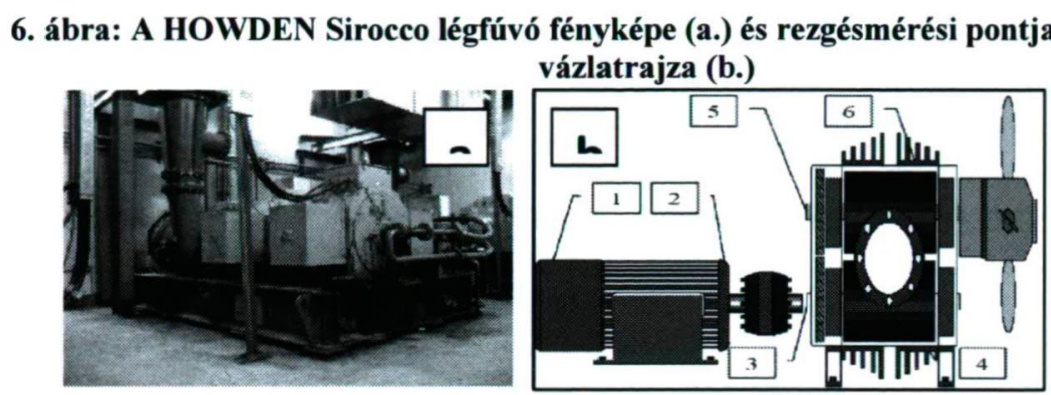

Forrás: Saját fotó, saját szerkesztésủ ábra

A 6. ábrán látható légfúvó egy élelmiszeripari folyamat, az élesztőgombák fejlődésének levegőellátását biztosítja. Az ipari méretủ termelés során a max. $40.000 \mathrm{~m}^{3} / \mathrm{h}$ levegőszállítást, gyorsító áttételü fogaskerék hajtómüvön keresztül $\mathrm{P}_{\text {motor }}=1100 \mathrm{~kW}$ teljesítmény, $\mathrm{n}_{\text {motor }}=$ $2976 \mathrm{1} / \mathrm{min}$ motor-, és $\mathrm{n}_{\text {rotor }}=90001 / \mathrm{min}$ járókerék fordulatszámon biztosítja.

A gép, termelésben betöltött szerepe kulcsfontosságú, müködésképtelensége esetén, tönkremegy a termék, így naponta akár több tízmillió forintos kár is keletkezhet. A 6.b ábra 6os számú kihajtó csapágyon rezgés-védelmi rendszert telepítettek, amely 4 másodperc után és $6 \mathrm{~mm} / \mathrm{s}$ rezgéssebesség RMS érték felett leállítja a motort. A folyamatirányító rendszer a terhelést fokozatmentesen állítja a diffúzor segítségével a pillanatnyi levegőigénynek megfelelően. A motor fordulatszám tehát állandó, de a változó lapátszög beállitással fokozatmentesen változik a motor terhelése és ezzel a szállított mennyiség is.

A légfúvón, a gép műszaki átadás átvétele óta 1998-tól 2006-ig két-három hónaponként a 6.b ábrán látható mérési helyeken, ugyanazon müszerrel és mérési beállításokkal, rendszeresen mértem a rezgéseket. Az un. „multi-paraméteres” rezgésdiagnosztikai vizsgálatot SKF MICROLOG CMVA 60 rezgésanalizátorral és Wilcoxon CMSS 786 kombinált magas frekvenciás piezoelektromos érzékelővel a gép csapágyazási helyein, vízszintes függőleges és axiális mérési irányokban végeztem. Az adatfeldolgozás Prism4 for Windows szoftverrel történt. A rendszeres mérés és a pontos diagnózisok eredményeképpen a gép a tervezett nagyjavítási ciklus kétszeresét élte meg felújítás nélkül, de 2006-ban egy vállalati átszervezés kapcsán először csökkentették, majd teljesen megszüntették a méréseket. A karbantartásokat elvégeztették a szakszervizekkel, de nem a mủszaki állapotra, hanem a cégek által javasolt ,szokásos” TMK jellegủ csereintervallumokra támaszkodtak.

2009-ben a megfelelő müködés ellenére döntöttek a gép több millió forintos felújításáról. Ennek során szétszerelték az egész gépet, a motoron az álló és forgórész elektromos felújítását, tengelykapcsoló motor és hajtómủ csapágycserét hajtottak végre. 
7. ábra: A légfúvó 6. csp. vízszintes rezgéssebesség RMS spektrumon belüli változásai 1998 -2012

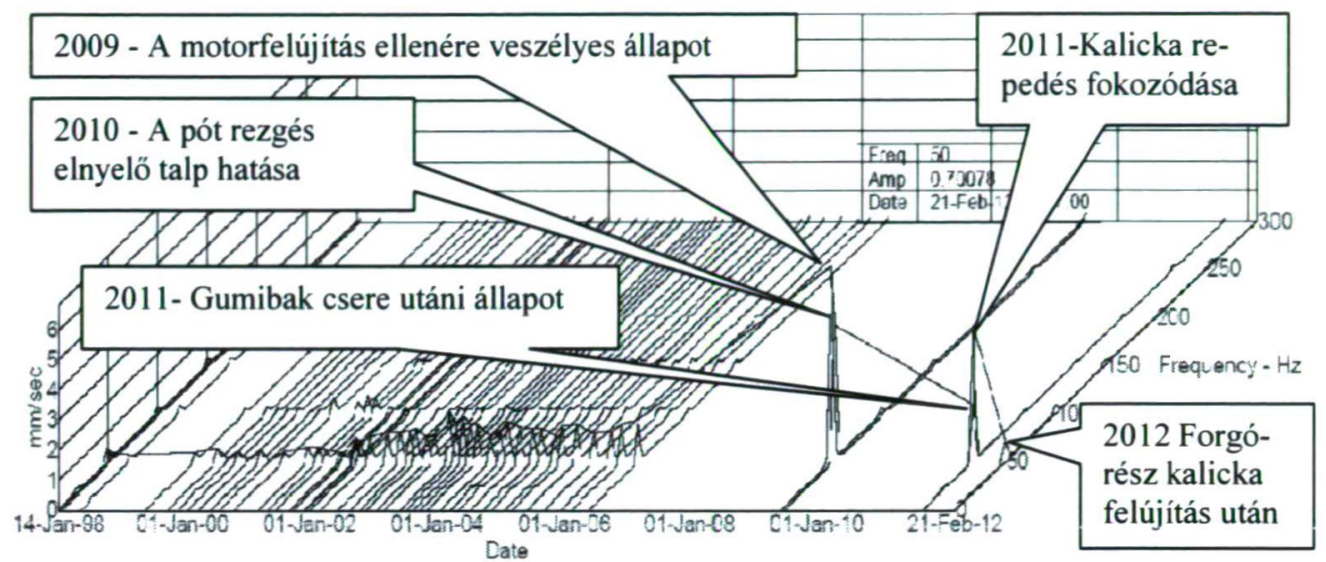

Forrás: Saját szerkesztésű ábra (SKF - Prism4 for Windows)

A jegyzőkönyvek szerint a felújítást végző cég a motort kiegyensúlyozta, elektromosan felújította, ellenőrizte, és ügyelt a tengelybeállításra is. Ennek ellenére az indulás után olyan veszélyesen magasra növekedtek rezgések, lásd. 7. ábra, hogy a rezgésvédelem kb. 40-50\%-os terhelésen leállította a gépet. A karbantartás eredményeként, sajnos a gép gyakorlatilag használhatatlan volt, felterheléskor a rezgésőr továbbra is letiltott 6 - $7 \mathrm{~mm} / \mathrm{s}$-os rezgések miatt. Ekkor hívtak „vissza” engem.

A spektrumanalízis és a multi paraméteres rezgésvizsgálat során, a rezgésspektrumon belüli változásokból megállapítottam, hogy a domináns, veszélyes a fúvó minden mérési pontján a motor $50 \mathrm{~Hz}$-es forgási frekvenciáján jelentkeznek. A vázszerkezeten ennél még magasabb, $15-25 \mathrm{~mm} / \mathrm{s}$ rezgésszintet is tapasztaltam. Sajnos ezek a szimptómák egyszerre utalhattak a motor kiegyensúlyozatlanságára, a motor, vagy a vázszerkezet fellazulására (gumibak elöregedésre), tengely-beállítási, illetve elektromos problémára. Az egész vázszerkezet olyan erősen remegett, hogy gépre szerelt kisebb alkatrészek közül több is tönkrement, a rezgések még az olajat is ,kirázták” az olajtartályból.

\section{8. ábra A légfúvó mozgás-animációs modellje (a.) és a mozgás-animáció eredménye (b.)}
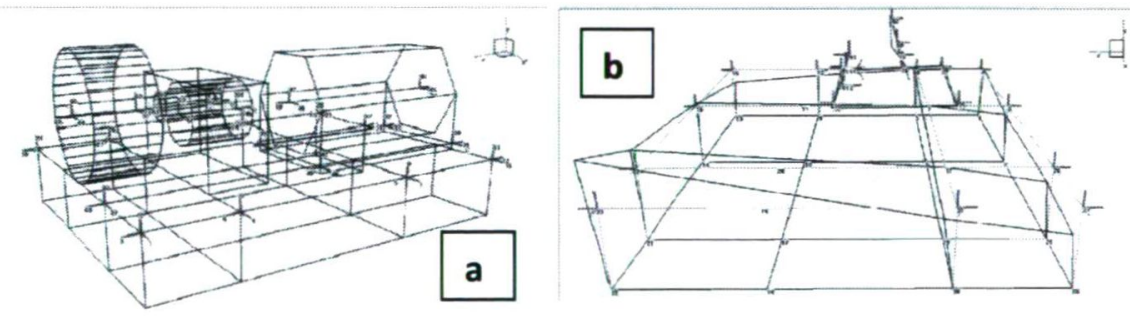

Forrás: Saját szerkesztésủ ábrák (Vibshape, 2002)

A spektrumanalízis eredményeinek tisztázása, a többféle hibára utaló rezgésjelek szétválasztása érdekében javasoltam a mozgás-animáció alkalmazását. A mozgás animációs vizsgálatot ennél a berendezésnél is a „Vibshape” szoftverrel és az „EasyViber 64" digitális rezgésanalizátorral, valamint optikai fordulatszám és fázisszög mérő készülékkel végeztem el. A vizsgálat menete megegyezett az előző fejezetben ismertetett elökészítési, mérési, kiértékelési folyamattal, de itt több mérési pontot és irányt kellett terveznem. A fúvó modellje a 8.a. ábrán, a maximális kitérés kimerevített képe a 8.b. ábrán kísérhető figyelemmel. 


\section{Megállapítások a légfúvó diagnosztikai vizsgálatai alapján:}

$\mathrm{Az}$ animáció eredményei két fontos mozgásra hívták fel a figyelmemet. Elöször is a vázszerkezet veszélyes mértékü billegésére (lásd.8.b. ábra), amely feltámasztási, vázszerkezet merevségi, valamint a rezgéselnyelő talpakkal kapcsolatos problémákat mutat. Másrészt a motor és a hajtómü tengely ellentétes mozgása figyelhető meg, amely tengely beállítási hibát feltételez. A magas $50 \mathrm{~Hz}$-es frekvencia alapvetően a gumibakok nem megfelelö rezgés elnyelő képességére, motor forgórész kiegyensúlyozatlanságra, elektromos problémájára utal.

\section{Javasolt és elvégzett beavatkozások:}

Egy ilyen nagy értékű gép felújítása komoly gazdasági következményekkel is jár ezért a feltételezett hibák kijavítását fokozatosan, az „olcsóbb” beavatkozásokkal kellett kezdeni.

A vázszerkezeten több helyen csavar fellazulást találtam, de jelentősen a meghúzásuk ellenére sem csökkentek a rezgések. Ezek után a vázat a három legmagasabb rezgésü helyen pót rezgéselnyelö talpakkal, aláhangolással próbáltuk „,elnyeletni” a gerjesztő eröket, de ez sem jelentett végleges megoldást, mert a fúvót így is csak $70 \%$ terhelésig lehetett használni.

Ezután a pontos tengelybeállítás és a rezgéselnyelö talpak cseréje a rezgéseket átmenetileg csökkentette, azonban 2011 -ben ismét növekedést tapasztaltunk.

Ekkor javasoltam a motor elektromos ellenörzését, bár a 2009-es jegyzökönyvek szerint a motor felújitása rendben volt. Az álló és forgórész elektromos ellenörzése, a mágneses mezỏ ingadozását jelezte, amely forgórész excentrikusságára, vagy kalicka repedésére utalt. A kalicka repedés kizárására endoszkópos vizsgálatot végeztünk (úgy gondoltuk ezt a felújítás során észrevették volna), ez azonban negatív eredménnyel zárult, a fogórész mindkét végén olyan mértékü repedéseket tapasztaltunk, hogy a gép azonnali leállitását és a forgórész újbóli felújítását javasoltam az üzemeltető cégnek, amelyet 2011 év végére tudtak elvégezni.

\section{A légfúvó múszaki állapotában bekövetkezett változás, konklúzió:}

A javítás után a veszélyes rezgések látványosan elfogadható szintre csökkentek, jelenleg nem csak a motoron, hanem a hajtómüvön és a vázszerkezeten is jó rezgésszint és megfelelő műszaki állapot tapasztalható. A 7. ábra spektrumaiban egyértelmủen beazonosíthatók, követhetők a hibás és jó műszaki állapot rezgésamplitúdói, melyek szemléletesen bizonyítják, hogy a forgórész kalicka csere elérte célját, a légfúvó újra $100 \%$-os terhelésen üzemeltethető.

\section{KÖVETKEZTETÉSEK}

A kísérleti mérésekkel bizonyítottam, hogy a „Vibshape” mozgás-animációs szoftverrel és Easy Viber64 rezgés-analizátorral láthatóvá tehetö, megérthető és elemezhetö a gépszerkezetek üzem közbeni mozgása. A kísérletek során az általam létrehozott mesterséges hibákat, az animáció a valóságnak megfelelően jelenítette meg. A légfúvó saját mérési tapasztalatomból vett példáján keresztül igazoltam, hogy a módszer az ipari gyakorlatban is jól alkalmazható, hatékonyan kiegészíti a spektrum analízis által szolgáltatott információkat.

\section{KÖSZÖNETNYILVÁNÍTÁS}

A cikk és előadás a TÁMOP-4.2.1.B-11/2/KMR-2011-0001 „Kritikus infrastruktúra védelmi kutatások” projekt kutatási eredményeinek felhasználásával készült. „A projekt az Európai Unió támogatásával, az Európai Szociális Alap társfinanszírozásával valósul meg."

\section{FELHASZNÁLT IRODALOM}

Szabó József Zoltán : $\quad$ Rezgésdiagnosztikai vizsgálatok és haditechnikai alkalmazhatóságuk kutatása Doktori Ph.D. értekezés ZMNE, 2011.

Rahne Eric: Gépszerkezetek mozgás-animációs vizsgálata PIM Kft. Kiadványa, 2004. www.pim-kft.hu 